ECONOMIC THEMES (2019) 57(1): 111-125

\title{
INSTITUTIONS AS THE DRIVER OF ECONOMIC GROWTH IN CLASSIC, NEOCLASIC AND ENDOGENOUS THEORY
}

\author{
Slobodan Cvetanović \\ University of Nis, Faculty of Economics, Republic of Serbia \\ $\bowtie$ slobodan.cvetanovic@eknfak.ni.ac.rs
}

\section{Uroš Mitrović}

University Union - Nikola Tesla, Faculty of Sport, Belgrade, Republic of Serbia

$\bowtie$ umitrovic@gmail.com

\section{Marko Jurakić}

PhD student, University Educons, Faculty of Business Economy, Sremska Kamenica, Republic of Serbia

$\bowtie$ markovimal@gmail.com

UDC

330.341.1:

330.35

Review paper

\begin{abstract}
The research in this paper focuses on the perception of institutions as the drivers of economic growth. A critical presentation of the views of classical, neoclassical and endogenous growth theorists on this issue is given. It was pointed out that the classical economic theory presented in the works of Smith, Ricardo and Malthus implies the importance of the existence of an appropriate institutional framework for initiating economic growth. The attitude of the classics is that the state can stimulate economic growth through various measures aimed at building quality institutions. On the contrary, the neoclassical growth theory has completely neglected the treatment of institutions in the analysis of economic growth. Institutions as drivers of economic growth are not taken into account in the Robert Solow's model. However, broadly speaking, it can be assumed that the impact of institutions on the initiation of economic growth is embedded in the category of residuals and the premise of the existence of a high substitution of production factors. But, this fact, even from a distance, does not call into question the general conclusion about the unacceptable neglect of the importance of institutions in explaining the physiology of economic growth by neoclassicists. Finally, the paper emphasizes the fact that only with the emergence of an endogenous growth theory, the question of the underdevelopment of the institutions as an important model of slow economic progress of certain countries is explored. Unfortunately, the developed theoretical models of growth, which include institutions as a full concept, still do not exist in the endogenous theory of economic development.
\end{abstract}


Received: 27.02.2019

Accepted: 28.03.2019
Keywords: institutions, economic growth, drivers of economic growth, models of economic growth, classical theory, neoclassical theory, endogenous growth theory.

JEL classification: B22

\section{Introduction}

Economic growth means increasing the value of a country's production over time. Continuous economic growth is an important prerequisite for solving the central economic task in each community, defined as a means to satisfy the growing needs of people as much as possible by using the definition of limited resources (Cvetanović, 1997).

Economic growth in itself is not a guarantee of social prosperity. But, in real terms, the growing standard of living and social progress cannot be spoken without economic growth over a longer time frame. In the conditions of dynamic economic growth, the choice of social goals is far simpler and incomparably less controversial process than in cases where this condition is not fulfilled (Dragutinović, et al, 2015).

The issues of effective economic growth have always been in the focus of economic theory. However, the real flood of works devoted to this phenomenon occurred in the years after the Second World War. The analysts' main concern was to seek answers to questions about why some countries are rich and others poor, why certain economies grow faster than others, and what are key drivers of economic growth (Viplos \& Burda, 2016).

The fact is that over the past decades there have been numerous attempts to launch economic growth, but only a few have succeeded. Looking for the most common reason of preventing the intensification of economic growth in underdeveloped economies, a number of growth researchers concluded that this is an effort by individuals and groups to provide rent, to use political means for the purpose of taking out of society more than to justify their contribution to the creation of a new value. This is directly related to the lack of a quality institutional framework in countries that fail to approach the developed economies (Acemogly, 2009). Actually, the essence of the existence of quality institutions is that, by creating rules of the game in the economic and political sphere, adequate incentives influence the behavior of economic entities in the direction of improving the quality of key macroeconomic performances (North, 1994).

Societies with non-governmental institutions not only grow slower in the long run, but as a rule have problems with continuous changes in the economic structure. Strong institutions influence high levels of income per capita, as they shape the conditions for investment and growth. In areas where corruptions and incomplete protection of property rights are expressed, for example, low 
investment returns become available or they are not present at all. In the final analysis, this logically affects the slowdown in economic growth.

The subject of the research in this article is the institutions and their influence on economic growth. The aim is to critically examine their place in the theories of growth of classics, neoclassics and the representatives of endogenous growth.

The defined object and purpose of the research determined the composition of the work. After the introduction, a shorter theoretical explanation of the essence and nature of the key attributes of the category of institutions is followed. The third section of the paper explains the most important fundamental drivers of economic growth. The fourth section analyzes the views of classical, neoclassical and endogenous theory on the importance of institutions in the launch of economic growth. The fifth section of the article is devoted to concluding observations.

Although the field of economic theory related to economic growth research is rather well developed and includes some of the greatest economists of our time, there is still no clear answer to the question what are the most important drivers of long-term economic growth and to what extent they generate the economic growth of individual countries and regions. This particularly refers to the assessment of institutions in the capacity of drivers of economic growth. In this sense, the authors think that this work can at least symbolically contribute to the understanding of the importance of institutional reforms, especially in the countries of delayed transition, such as all countries of the Western Balkans, including the Republic of Serbia.

\section{Direct and fundamental driver of economic growth}

The neoclassical growth model of Robert Solow, from whom, as a rule, every modern analysis of the phenomenon of growth begins, focuses on three so-called direct drivers of economic growth - physical capital, human labor and technological change. Without sacrificing their significance, one should keep in mind that economic growth depends to a large extent on many other so-called fundamental drivers, which imply institutional and other conditions for efficient use of basic development factors. Fundamental factors must be included in the growth analysis, in order to arrive at an acceptable answer to the question of what reasons prevent individual countries from investing more in physical and human capital, and technology (Acemogly, 2009).

The fundamental drivers of economic growth determine to a significant degree the ability and capacity of the country to accumulate direct factors of production and invest in the production of knowledge. Among the fundamental factors of growth the most significant are: population growth, development of the financial sector, quality of the macroeconomic environment, trade regimes, state size, distribution of income, political and social environment (Snowdon \& Vane, 2005). 
Hall \& Jones, (1999), considering the question of why some countries are rich and others poor, concluded that, among other things, formal and informal institutions, as well as policies implemented by the state, play a very important role in the growth process. If public and social infrastructure stimulates production and investment, economic growth begins. Otherwise, there is an economic downturn (recession). Entrepreneurs will not invest in a country if their prospects to make positive returns are bad. Likewise, if there is a bribe, corruption, theft, investors' motives will be significantly reduced. Taxation, regulation, lobbying can also affect the motivation of the investor, but to a lesser extent than the previously mentioned causes.

Acemoglu (2009) decodes four types of fundamental drivers of economic growth: the drivers of "happiness", geographic drivers, drivers of cultural influences and institutional drivers.

Under the factors of "happiness", we mean a whole group of fundamental factors that explain the divergent paths of economic growth of countries that have similar developmental predispositions. In this case, the different choice of the country within a multiple balance leads to far-reaching consequences. These consequences mean that it is not often possible to accurately predict which balance will be chosen by different countries, so it is possible that two otherwise identical countries end up with significantly different rates of growth and living standards.

The second group includes all the factors that affect individuals as part of the geographical, ecological and physical environment in which they live. They include soil quality, natural resources, climate and topography. For example, poor soil quality, lack of natural resources and adverse climatic conditions can affect the efficiency of technology.

The third group presents the factors of the cultural pattern. This includes the values and preferences that affect the economic behavior of individuals. More broadly, culture can have an impact on economic performance through the impact on the individual's inclination to savings and through the impact on the level of cooperation and trust between individuals, which together affect the production possibilities of the economy.

The fourth group represents institutional factors that relate to rules, regulations, laws and policies that affect economic incentives for investing in technology, physical and human capital. What separates these factors from the previous ones is that they are in the broader sense the choice of the members of society themselves. Thus, institutional drivers are, by their nature, endogenous and are the result of a balanced choice of the whole society or of certain powerful groups, unlike the previously mentioned factors of exogenous character (North, 1990). Assuming that institutions are a significant driver of economic growth, it follows that institutional reforms in countries can lead to desirable changes in the behavior of economic actors in a way that will lead to better development performance. 
In the continuation of the work, the emphasis is placed on the perception of key characteristics of institutions as one of the fundamental drivers of economic growth and, in particular, their place in significant economic growth theories.

\section{Institutions as a fundamental driver of economic growth}

Institutions include: rules that determine who is authorized to make decisions in a particular area, which activities are allowed and which are not, the procedure to be followed, the information structure that determines the quality, cost and quality of the information on the basis of which decisions are made. Institutional rules limit the choice of economic actors, since they strictly prohibit certain activities, discourage others, and encourage third parties. In other words, institutional rules in a certain way determine the structure of incentives in the economy, i.e. determine which activities will be profitable, which organizational and managerial forms will prevail in society, how coordination of economic activity will take place, etc.

The reasons for the creation of institutions are numerous. In the literature, the need for efficiency gains and cost reductions are often indicated as the most important reasons for the emergence of institutions (Acemoglu 2003). According to the first approach, societies are selected by those institutions that maximize their total income surplus. How this surplus will be distributed among different groups does not affect the choice of institutions. The basis of this approach is the Coase theorem, which says that in a situation where different economic groups negotiate without cost, they will be able to determine the distribution of potential externalities. At the core of the second approach lies the view that institutions have been built to solve economic problems, such as reducing transaction costs, securing contract obligations, etc.

Institutions play an important role in increasing the functionality of society, and in particular in increasing economic efficiency. They must provide predictable and coherent rules, but in spite of this, institutional changes and adjustments to social preferences, technology, political and socioeconomic structures and external factors are necessary. It is important to distinguish the institutional environment that is a set of basic political, social and legal rules from institutional arrangements that relate to agreements between economic units on how to cooperate. Such a distinction emphasizes the fact that institutions always represent normative rules, on the one hand, and that the parties involved have to respect the agreed agreements on the other. Accordingly, institutions always consist of two components, rules and their executive characteristics.

There are numerous divisions of institutions in the literature. Some authors share the institution on external and internal ones. External institutions are formal rules enforced by the monopolistic coercion of the state. Internal institutions are subject to 
private supervision and can be classified according to different performance characteristics.

The formal and informal institutions should be distinguished. Formal institutions are constitution, statutes, customary law and other state decisions and regulations. These institutions determine the political system (structure of government, civil rights), economic structure (property rights, contracts) and the system of coercion (legislation, police), and they are carried out by state authorities through sanctions. Informal institutions are tradition, customs, moral values, religious beliefs and all other norms of behavior adopted over time. They embody the prevailing views and views of the community in the world, accumulated knowledge from the past and the ruling system of values. Informal institutions can be transmitted by imitation or oral tradition. They have an important role in the structure of elections, that is, in the short-term and long-term development of societies.

In the development process, the need for formal institutions is increasing ever more complex transactions, which could hardly be managed efficiently through informal institutions. However, this does not mean that informal institutions become useless or lose their relevance. On the contrary, it is important that any change in the institutional environment to be taken into account, or to be incorporated into existing institutions. This prevents the creation of a parallel system that is usually ineffective and involves high costs.

Formal institutions define the framework within which businesses operate. The ownership rights and the implementation of the contract are regarded as institutions that shape the market, without which exchange would not be possible.

Fundamental institutions such as the constitution or the rule of law contribute to political stability, the prevention of corruption, the raising of the efficiency of the public sector and the protection of private property rights from unlawful appropriation of private individuals or the state. Formal institutions gain importance in relation to informal institutions, the expansion and deepening of the scope of market exchange. The establishment of formal institutions has high fixed costs, but low marginal costs, while informal institutions include high marginal costs (Rodrik 2003, p. 23).

According to the role they have, it is possible to distinguish between economic and political institutions. Economic institutions refer to the economic rules of the game, which in particular refers to the degree of implementation of property rights, a set of contracts that can be written and applied. Examples of economic institutions include individual proprietary rights, commercial law, contract law, patent law, various types of credit arrangements, and so on. Political institutions regulate the limitation of political power and determine how political power influences the change of government. Common examples of political institutions include the constitution, electoral rules, constraints imposed by the executive, etc. (Acemoglu, 2003). 


\section{The place of the institutions in the more significant theoretical explanations of economic growth}

Theoretical and empirical research of the link between the economic success of countries and the quality of the institutional environment emerged in the years of the eighth decade after the promotion of a movement in science by which institutions constitute a key driver of economic growth (North \& Thomas, 1973). Institutions do this in different ways - from creating the preconditions for an efficient allocation of resources that lead to the most productive uses, to the creation of an environment in which the commercialization of knowledge in innovation predominantly determines the economic dynamics. It should be pointed out that a smaller number of research found the existence of conditional interdependence between institutions and economic growth. However, there is almost no research that has found a negative correlation between effective institutions and economic growth.

The basic goals of economic growth are well known: increasing quantity and quality of production and raising living standards in the long run. Some national economies are underdeveloped either because they lack resources or because their knowledge and skills to efficiently use the resources they have are possessed. Nevertheless, explanations of the causes of economic underdevelopment, as well as the recommendations offered by the theoreticians of economic growth and development in order to overcome such a situation, are very different.

\subsection{The place of the institutions as a driver of economic growth in classical economic theory}

Classical economists were preoccupied with the dynamics of economic growth in their study. They considered growth of population and accumulation of physical capital necessary assumptions of economic growth. Capital accumulation is determined by the profit margin. It creates demand for work, stimulates innovation and allows division of labor. The increase in population results in an increase in food demand, which is characterized by declining yields. Innovations stimulate growth and annihilate the tendency of declining yields.

Classics studied value theory and distribution theory in order to better understand the important economic, political and social changes that occurred in their time, but also to predict what would happen in the long run in these economies (Cameron, 2007). Their analyses show the conditions of production at that time in which the country as a production factor was of great importance. Accordingly, the classics did not have an analytical instrument that had to do with the production functions and utility functions, which was created later by the emergence of a marginalistic trend in economic science. Therefore, the analysis of economic growth in classical economic theory was incomplete. However, the fact 
is that many characteristics of modern models of growth pull their roots out of theoretical considerations of classical economists. This primarily refers to the classical viewers on the importance of the division of labor, the improvement of innovation, the growth of the population, the manifestation of declining yields, which are present in most of the modern models of economic growth.

Theoretical explanations of the classical economic growth can be divided into optimistic and pessimistic theories (Eltis, 2000, p. 8). A representative of the first group of theories is Adam Smith, and representatives of the second group of theories are David Ricardo and Thomas Malthus.

Adam Smith emphasized that economic growth is above all a function of labor and productivity. He pointed to the crucial role of accumulation of capital in new employment and productivity growth, which is of primary importance for the creation of the wealth of the people. The author has decisively argued that without the growth of accumulation of capital there is no improvement in the economic results of the country. The wealth of the people can be increased thanks to the division of labor and the market economy in the conditions of the economy of a perfectly competitive form. The size of production per capita basically determines the skills and abilities that people have as well as the share of employees in useful work in the total population. Capital accumulation is the main factor in increasing labor productivity.

The division of labor is a powerful generator of labor productivity growth. It is therefore understandable that Smith's interest in issues is related to improving the skill of workers, saving time in the transition from one type of work to another and, far more importantly, it is related to the results that come from the use of new means of work. Smith indicates an innate tendency for people to exchange one thing for another. This trait of people is deeply rooted in their attitude and it is the cause of labor division. Finally, Smith observes that division of labor is limited to market size. The larger market leads to a more pronounced division of labor among enterprises. A more pronounced division of labor, in Smith's opinion, generates productivity growth in all firms. This Smith's logic is implicitly based on the hypothesis that every single firm operates with constant yields, and that at the level of the overall economy, there is a growing yield. Smith's analysis in rudimentary form indicates the concepts of technological change and the effects of learning by work, which will be very important theoretical constructs of the theory of endogenous growth at the end of the twentieth century. Smith anticipates the following two ideas, which are present in the theory of endogenous growth: a) scientific information is generated within the economic system thanks to a number of specialized activities; and b) new technological knowledge is, or will become, public goods are already available or will become available to everyone. (CluniesRoss, et al, 2009.) 
According to Smith, the rate of economic growth depends on the decisions and actions of the participants, especially their preference for savings, as well as the creativity and innovation that people possess in given social and historical circumstances. Special emphasis has been put on the endogenous movement of new knowledge that can be economically efficiently used. New technical knowledge is treated as a public good or has a tendency to become so. There are no unequivocal growth restrictions. Additional workforce, which is necessary in the accumulation process, is generated by the process itself. Decreasing yields due to the scarcity of natural resources can be offset by an increase in productivity achieved by division of labor.

From the point of view of the defined object and objectives of the research in this paper, we should point out the fact that Smith emphasized the importance of having an appropriate institutional framework for the smooth development of economic growth. He considered that there were a number of institutional measures that could be used to stimulate growth, for example, free trade, a certain type of deregulation, decentralization, and so on. A stable and efficient legislative and legal system is of primary importance for the process of economic growth. The state should not be involved too much in economic life, because in the long run it only diminishes the efficiency of the market.

David Ricardo dealt with dynamic analysis in his research. His distribution theory was closely related to growth theory. He considered that the pursuit of accumulation of capital was the primary motive in the process of economic growth. Capital accumulation implies savings, and savings depend on the available income. If the profit rate is high, the capitalist will spend less and save more, and vice versa. Therefore, capital accumulation is a growing function of disposable income (Eltis 2000, p. 10).

Capital accumulation increases demand for labor, which acts in the direction of rising wages on the market. Border capital products and labor are subject to the law of declining yields. Although real wages are constant at an existential minimum, the decline in the marginal product means that the relative share of labor (wages) is rising, and the relative share of capital (profits) decreases. Beyond these profits, capital accumulation will again appear, but now at a reduced rate. The growth process will continue until the profits fall to zero. At this stage, capital accumulation ceases, economic progress is stopped, and the system gets into a stationary state.

Ricardo noted that the institutional framework could have a negative impact on economic growth. Thus, the Law on Cereals meant a rise in wages and a fall in profits. Lower profits led to lower savings and lower investment rates, which in turn led to less accumulation of capital and, in analogy to that fact, to slower economic growth. 
Thomas Malthus explored the disproportion between the rate of population growth and food supply. He has determined that the number of inhabitants on the Earth is doubled every twenty-five years, i.e. it is increased by geometric progression. On the contrary, the supply of food cannot be increased faster than arithmetic progress in the most favorable conditions. According to Malthus, population growth is the final result of the overall economic development process. However, an increase in population cannot occur without a proportional increase in wealth. He considered that only an increase in population could not act as an incentive for economic growth, but has an impact in the situation where there is an increase in effective demand.

Malthus was the first theoretician to deal with the problem of dynamic equilibrium in the economy, and the first to deal with a comparative increase in aggregate supply and aggregate demand. He argued that the wealth of the country depends on the quantity and productivity of the production factor. Furthermore, he considered that for a stable growth in the long run, it is important that demand be such as to provide sufficient incentive on the supply side.

Institutions, such as the legislative system, also played an important role here, so Malthus argued that the aggregate demand would be sufficient until they were valued by the Laws on Cereals. Namely, the Laws on Cereals were a source of high rents and, as long as they provided sufficient income to landowners, accustomed to good life, there was no shortage of aggregate demand.

\subsection{Neglecting Institutions as the Motivators of Economic Growth in the Neoclassical Theory.}

Neoclassical literature deals with the process of economic growth for an adequate coefficient of technical equipment and the process of establishing a long-term balance. In the absence of external "shocks" or radical technological changes, all economies will strive for zero growth. It turns out that the GDP pc increase, according to the neoclassical logic, becomes a temporary phenomenon which is the result of technological changes. It is believed that this theory failed to provide a satisfactory explanation for the unbelievably consistent pace of economic growth in most of today's economically advanced countries. Any increase in GDP pc that cannot be attributed to short-term adjustments in labor or capital funds is attributed to the third category, most commonly called Solow's residual. This residual, in spite of its name, is responsible for, roughly speaking, 50\% of historical growth in industrialized nations. In an ad-hoc way, neoclassical theory attaches most of the economic growth to an exogenous or completely independent category of technological change. Although logically possible, this approach has at least two insurmountable drawbacks. First, using a neoclassical framework of work, it is impossible to analyze the determinants of technological changes, because in this approach the dynamics of technological changes are completely independent of the 
decisions of economic actors. Second, the theory fails to explain the great differences in the residuals of many countries with similar technologies (Sredojević et al, 2016). The center of studies in neoclassical growth theory was focused only on several key drivers of growth; accumulation of physical capital, labor, productivity and the category of technological changes. The economy converts to an equilibrium rate of growth, that is, an equilibrium state in which each variable grows at a constant rate. Whenever the economy is out of an equilibrium rate of growth, no matter whether there is too little or too much capital per capita, forces begin to act on the economy to return to the state of long-term equilibrium (Mervar 1999). As the amount of capital per capita rises or falls, the marginal productivity of capital falls or increases due to the declining yields of the production factor, so the capital relation approaches a constant value. The state can influence the savings rate and, in case of an equilibrium growth rate, the increase in savings will result in higher equilibrium values of the coefficient of technical equipment. The growth of savings on which the state can operate, in the short term increases the rate of GDP increase per worker, but not in the long run. The change in the saving rate affects the level of output per worker. In the short term, growth can arise from capital accumulation, but long-term growth in output per worker depends exclusively on the category of technological change.

The growth model of Robert Solow shows the extent to which some productive factors contribute to economic growth. The model is based on a number of assumptions, and one of them is that property rights are safe. Therefore, the lack of this model, in the light of the defined subject of research in this paper, is reflected in the fact that the model completely abstracts the importance of the quality of institutions in researching economic dynamics. This, despite the fact that the institutions can be treated as a component of the residual in the broadest sense of the word, includes all factors of economic growth, other than labor and capital in the Robert Solow model. Although neoclassical growth models are still current in the economy and explained many elements of the growth mechanism, they almost completely ignored the influence of fundamental growth drivers, among which the particular place belongs to the institutions themselves. The question to which Robert Solow model of economic growth did not answer is why in some countries economic actors invest more in physical and human capital, or why they invest more funds in innovations than in some other countries. But the neoclassical growth theory has unambiguously demonstrated that efficiency and productivity are the dominant degree of the result of qualitative changes in the economic system. By this, the neoclassical theory has made the way to the emergence of the endogenous growth theory of the nineties in the previous century.

\subsection{Institutions in endogenous explanations of economic growth}

Theoretical exponents of endogenous growth emerged at the beginning of the last decade of the previous century. In their epicenter, there is an effort to explain in a 
more acceptable way the incompatibility of world practice from some of the neoclassical theory. Almost all endogenous economic growth theories emphasize the role of public policy in the promotion of economic growth, especially in the field of development of infrastructure and human capital.

The protagonists of endogenous explanations of growth try to explain, in a different manner, the mechanism of action of the key drivers of the economic advancement of the market leading countries in the world, or to recognize the most significant internal causes of economic lagging of a large number of national economies. Among them, categories of knowledge and innovation, public and social infrastructure seem to have the most significant role.

Models of endogenous growth have some structural similarities with neoclassical counterparts, but they differ significantly in assumptions and formed conclusions. First, models of endogenous growth reject a neoclassical assumption of a reduction in marginal returns of capital, starting from the view that a situation of unintended yields is possible. Second, they recount the role of externalities in determining the rate of return of new capital investments. Assuming that public and private investment in human capital generates externalities and productivity improvements that compensate for the tendency of declining yields of factors, endogenous growth theory requires a way to explain the existence of growth in yield and conclusions of neoclassical models of economic growth. Third, which is also the most important in the context of the subjects and objectives of the research in this paper, in a number of works concerning endogenous economic growth, institutions and policies of the state that stimulate investment and production growth, and do not spend and search for rent have the most important role. The search for rent can be defined as the reallocation of ownership rights through political intervention rather than market competition (Hall \& Jones, 1999).

An important conclusion of endogenous growth theory is that it remains dependent on many traditional neoclassical assumptions, which are often unsuitable for developing countries. Therefore, its applicability is limited, especially when two countries compare each other. For example, the existing theory fails to explain the low utilization rate of production capacities in countries with low GDP pc, where capital is an insufficient factor of production.

This theory is subject to criticism, and because of this, it paid great attention to the determinants of long-term growth, while the short-term and mid-term aspects were not considered. Finally, in some respects, empirical studies of endogenous growth theories today have limited support. Although still at the stage of formation, endogenous growth theory contributes to a better understanding of different experiences regarding long-term growth both in developed and developing countries. Although derived from neoclassical theoretical postulates, endogenous growth models modify the wider assumptions of traditional growth theory and function as a deepened explanation of the key carrier and fundamental drivers of 
the economic advancement of different countries. In the framework of the fundamental drivers of economic growth, they point out the importance of regulated proprietary rights. In an environment characterized by regulated ownership rights, incentives for savings, investments and innovations dominate.

\section{Conclusion}

Throughout history there have been numerous attempts to trigger economic growth, but only a few have succeeded more permanently. Looking for the most common way of slowing down or even disabling the process of convergence of less developed countries to the level of the GDP pc of developed countries, a number of growth researchers noted that this was an effort to secure an annuity, i.e. to use political means to take more than what the contribution to the growth of production implies.

The main characteristic of numerous approaches to research of the most important drivers of economic growth emphasized the partiality. The lack of a synthetic view of the problems of underdevelopment is a common feature of most of the theoretical explanations of economic growth drivers, ranging from classical economists to the present day. On the whole, there are few papers that competently explore the method of acceptable incorporation of individual drivers of economic growth into a compact entity.

Focusing on the importance of institutions as the driving force of development in classical and neoclassical theories of economic growth, the following conclusions have been drawn. First, the classical economic theory presented in the works of Smith, Ricardo and Malthus generally acknowledges the importance of the existence of an appropriate institutional framework for the undisturbed development of economic growth. Their view is that there are a number of measures on an institutional basis such as free trade, deregulation, decentralization, decimation of controversial Law on Cereals at that time, which can be used to stimulate economic growth. A stable and efficient legislative and legal system is of primary importance for the process of economic growth. The state should not be involved too much in economic life, because in the long run it only diminishes the efficiency of the market. Secondly, it can be noted that the neoclassical development theory is a step backward in terms of the treatment of institutions in the launch of economic growth. Non-clustered models of economic growth define the economy as a closed system in which goods and services are produced using capital and labor. Economic growth is achieved by larger quantities and / or higher quality inputs, or by technological advancement. In these models, institutions as drivers of economic growth are not explicitly included. But, broadly speaking, it can be assumed that their effect is incorporated into the category of residuals and the premise of the existence of a high substitution of production factors, but this fact does not distract from the general view of the unacceptable neglect of the importance of the quality of institutions in initiating economic growth. Thirdly, 
with the affirmation of endogenous growth theory, there is more and more talk about the underdevelopment of the institution as a model of slow economic growth in some countries. Unfortunately, the developed theoretical models of growth that include institutions as a rounded concept do not exist. Instead, the intuition and historical experience are dominated by empirical research.

\section{References}

Acemoglu, D. (2009). Introduction to Modern Economic Growth, Introduction to Modern Economic Growth, Princeton University Press.

Acemoglu, D. (2003). Lecture Notes for Political Economy of Institutions and Development, Massachusetts Institute of Technology

Cameron, G. (2007). Classical Growth Models, New Palgrave Dictionary of Economics, 2nd edition, University of Oxford.

Cvetanovic, S. (1997). Teorija ekonomskog razvoja, Beograd: Zavod za udžbenike i nastavna sredstva.

Burda, M., Viploš, (2016). Makroekonomija - evropski udđbenik, Beograd: Centar za izdavačku delatnost Ekonomskog falulteta Univeryiteta u Beogradu.

Clunies-Ross, A., Forsyth, D., Hug, M. (2009). Development Economics, McGraw-Hill.

Dragutinović, D., Filipović, M., Cvetanović, S. (2015). Teorija privrednog rasta i razvoja, Beograd: Centar za izdavačku delatnost Ekonomskog fakulteta Univerziteta u Beogradu

Eltis, W. (2000). The Classical Theory of Economic Growth, New York: Palgrave.

Hall, R, Jones, Ch. (1999). Why Do Some Countries Produce So Much More Output Per Worker Than Others? The Quarterly Journal of Economics, 114 (1), 83-116

Mervar, A. (1999). Pregled modela i metoda istraživanja gospodarskog rasta. Privredna kretanja i ekonomska politika, 9 (73), 20-61

North, D. C. (1994). Economic Performance ThroughTime, The American Economic Review, 84 (3), 359-368.

North, D. C. \& Thomas, R. P. (1973). The rise of the western world: A new economic history. Cambridge University Press.

Rodrik, D. (2000). Institutions for high-quality growth: what they are and how to acquire them, Studies in International Comparative Development, 35 (3), 3-31.

Snowden, B., Vane H. (2005). Modern Macroeconomics. Massachusetss: Edward Elgar Publishing, Inc.

Sredojević, D., Cvetanović, S., \& Bošković, G. (2016). Technological Changes in Economic Growth Theory: Neoclassical, Endogenous, and Evolutionary-Institutional Approach. Economic Themes, 54 (2), 177-194.

\section{INSTITUCIJE KAO POKRETAČ EKONOMSKOG RASTA U KLASIČNOJ, NEOKLASIČNOJ I ENDOGENOJ TEORIJI}

Apstrakt: Istraživanja u ovom radu su usmerena na sagledavanje institucija kao pokretača ekonomskog rasta. Dat je kritički prikaz stavova klasičnih, neoklasičnih i teoretičara endogenog rasta po ovom pitanju. Istaknuto je da je klasična ekonomska teorija prezentovana u radovima Smita, Rikarda i Maltusa imlicite uvažavala važnost postojanja odgovarajućeg institucionalnog okvira za 
pokretanje ekonomskog rasta. Stav klasičara je da država može različitim merama usmerenih na izgradnju kvalitetnih institzcija može stimulisati ekonomski rast. Suprotno, neoklasična teorija rasta je u potpunosti zanemarila tretmann institucija $\mathrm{u}$ analizi ekonomskog rasta. U modelu Roberta Soloua institucije kao pokretač ekonomskog rasta nisu uzete u obzir. Doduše, šire gledano, može se pretpostaviti da je uticaj institicija na pokretanje ekonomskog rasta ugrađen u kategoriju reziduala i premisi postojanja visoke supstitucije proizvodnih faktora. Međutim, ta činjenica ni izdaleka ne dovodi u pitanje opšti zaključak o neprihvatljivom zanemarivanju značaja institucija u objašnjenju fiziologije ekonomskog rasta od strane neoklasičara. Konačno, u radu je istaknuta činjenica da tek sa pojavom endogene teorije rasta nedvosmisleno počinje da se istražuje pitanje nerazvijenosti institucaja kao važnom uzorčniku sporog ekonomskog napredovanja pojedinih zemalja $\mathrm{Na}$ žalost, razrađeni teorijski modeli rasta koji obuhvataju institucije kao zaokružen koncent i u endogenoj teoriji privrednog razvoja još uvek ne postoje.

Ključne reči: institucije, ekonomski rast, pokretači ekonomskog rasta, modeli ekonomskog rasta, klasična teorija, neoklasična teorija, teorija endogenog rasta.

\section{Authors' biographies}

Slobodan Cvetanović is a Full Professor at the Faculty of Economics, University of Niš. He teaches Macroeconomics and Financing the Capital Development of the Economy (undergraduate studies), Open Economy Macroeconomics (postgraduate studies), and Macroeconomics and Macroeconomic Management (doctoral studies). Professor Cvetanović has authored over 400 scientific articles and about 40 books. As an author and coauthor, he has published articles in world's relevant magazines. His narrow fields of interest include macroeconomics, economic development; innovation, sustainable development.

Uroš Mitrović graduated in 1999 at the Faculty of Philosophy at Comenius University in Bratislava, Slovakia. He received the academic title of Master (2010) and a PhD degree (2013) at the Faculty of Management of Small and Medium Enterprises in Belgrade. During 2001, he attended Advanced Professional Courses in Marketing at Harvard Extension School, Harvard University, USA. He was elected Assistant Professor at the Faculty of Applied Management, Economics and Finance in Belgrade. He is the author of several scientific papers and textbooks in the field of marketing and management.

Marko Jurakić, is a $\mathrm{PhD}$ candidate at Business Economics Faculty, Educons University, Sremska Kamenica. He earned his MSc degree in 2015 from the Business Economics Faculty, Educons University, Sremska Kamenica.His professional and research interests include human resource management as well as continuing education and lifelong learning. He presented his work in numerous domestic and international conferences in the field of human resources management. He is currently employed as a business consultant for several businesses and acts as a guest lecturer at Educons University. 